\title{
Responses of soil methanogens, methanotrophs, and methane fluxes to land-use conversion and fertilization in a hilly red soil region of southern China
}

\author{
Huifeng Liu ${ }^{1,2} \cdot$ Xing $\mathrm{Wu}^{1,3} \cdot$ Zongshan $\mathrm{Li}^{1,3} \cdot$ Qing Wang ${ }^{1,2} \cdot$ Dan Liu ${ }^{1,2}$. \\ Guohua Liu ${ }^{1,3}$
}

Received: 24 October 2016 / Accepted: 10 February 2017 / Published online: 17 February 2017

(C) Springer-Verlag Berlin Heidelberg 2017

\begin{abstract}
Changes in land-uses and fertilization are important factors regulating methane $\left(\mathrm{CH}_{4}\right)$ emissions from paddy soils. However, the responses of soil $\mathrm{CH}_{4}$ emissions to these factors and the underlying mechanisms remain unclear. The objective of this study was to explore the effects of land-use conversion from paddies to orchards and fertilization on soil $\mathrm{CH}_{4}$ fluxes, and the abundance and community compositions of methanogens and methanotrophs. Soil $\mathrm{CH}_{4}$ fluxes were quantified by static chamber and gas chromatography technology. Abundance and community structures of methanogens and methanotrophs (based on $m c r \mathrm{~A}$ and $p m o \mathrm{~A}$ genes, respectively) were determined by quantitative real-time PCR (qPCR), and terminal restriction fragment length polymorphism (TRFLP), cloning and sequence analysis, respectively. Results showed that land-use conversion from paddies to orchards dramatically decreased soil $\mathrm{CH}_{4}$ fluxes, whereas fertilization did not distinctly affect soil $\mathrm{CH}_{4}$ fluxes. Furthermore, abundance of methanogens and methanotrophs were decreased after converting paddies to orchards. Fertilization decreased the
\end{abstract}

Responsible editor: Robert Duran

Electronic supplementary material The online version of this article (doi:10.1007/s11356-017-8628-y) contains supplementary material, which is available to authorized users.

Xing Wu

xingwu@ rcees.ac.cn

$\checkmark$ Guohua Liu

ghliu@rcees.ac.cn

1 State Key Laboratory of Urban and Regional Ecology, Research Center for Eco-environmental Sciences, Chinese Academy of Sciences, Beijing 100085, China

2 University of Chinese Academy of Science, Beijing 100049, China

3 Joint Center for Global Change Studies, Beijing 100875, China abundance of these microorganisms, but the values were not statistically significant. Moreover, land-use conversion had fatal effects on some members of the methanogenic archaea (Methanoregula and Methanosaeta), increased type II methanotrophs (Methylocystis and Methylosinus), and decreased type I methanotrophs (Methylobacter and Methylococcus). However, fertilization could only significantly affect type I methanotrophs in the orchard plots. In addition, $\mathrm{CH}_{4}$ fluxes from paddy soils were positively correlated with soil dissolved organic carbon contents and methanogens abundance, whereas $\mathrm{CH}_{4}$ fluxes in orchard plots were negatively related to methanotroph abundance. Therefore, our results suggested that land-use conversion from paddies to orchards could change the abundance and community compositions of methanogens and methanotrophs, and ultimately alter the soil $\mathrm{CH}_{4}$ fluxes. Overall, our study shed insight on the underlying mechanisms of how land-use conversion from paddies to orchards decreased $\mathrm{CH}_{4}$ emissions.

Keywords Land-use conversion $\cdot \mathrm{CH}_{4}$ fluxes . Methanogens $\cdot$ Methanotrophs $\cdot$ Fertilization

\section{Introduction}

Methane $\left(\mathrm{CH}_{4}\right)$, the second largest contributor to radiative forcing after carbon dioxide $\left(\mathrm{CO}_{2}\right)$, causes approximately $15-20 \%$ of the observed global warming (IPCC 2013). Agriculture methane emissions are crucial to the global methane estimates, and these emissions magnitude are highly dependent on land-uses and fertilizer application (Scheer et al. 2008; Liu et al. 2016). Paddy cultivations have long been recognized as the main contributors to anthropogenic $\mathrm{CH}_{4}$ emissions, ranging from 30 to $50 \mathrm{Mt} \mathrm{y}^{-1}$ (Sass et al. 1994), whereas aerobic upland soils 
are the second greatest global $\mathrm{CH}_{4}$ sinks, accounting for 6-10\% of the total atmospheric $\mathrm{CH}_{4}$ uptake or about $30 \mathrm{Tg} \mathrm{y}^{-1} \mathrm{CH}_{4}$ (IPCC 2013). Therefore, the expected land-use conversion from paddies to uplands could possibly mitigate the global warming potentials by reducing $\mathrm{CH}_{4}$ emissions.

It is urgently demanded to understand the extent to which land-use conversion from paddy fields to upland plots contribute to greenhouse gases budgets, but $\mathrm{CH}_{4}$ fluxes record from continuous measurements of paddy fields and upland plots are limited. In the recent decades, results from field measurements have demonstrated that converting from paddies to uplands would change soil from emission source to sink of atmospheric $\mathrm{CH}_{4}$ (Nishimura et al. 2008; Liu et al. 2016). The dynamics of $\mathrm{CH}_{4}$ in paddy fields significantly differ from those in upland plots in which aerobic decomposition process is dominant (Nishimura et al. 2008; Scheer et al. 2008). However, there have been far fewer field investigations on the underlying mechanisms of decreases in $\mathrm{CH}_{4}$ fluxes induced by converting paddies to uplands. Meanwhile, fertilization is the management practice most frequently used for paddy fields and upland plots (Wang et al. 2015; Fan et al. 2016). While it has been reported that fertilization had controversial effects on soil $\mathrm{CH}_{4}$ fluxes in different land-uses, ranging from positive (Wang et al. 2015), negative (Liu et al. 2016; Zhou et al. 2016), and no significant effects (Fan et al. 2016). Thus, adequate estimates of soil $\mathrm{CH}_{4}$ fluxes, coupling with the changes in land-uses and fertilization, would be more helpful for the global greenhouse gases emissions budget.

Generally, $\mathrm{CH}_{4}$ fluxes from soils are determined by the counterbalance of methane production and subsequent oxidation by methanogenic and methanotrophic microorganisms, respectively (Hanson and Hanson 1996; Watanabe et al. 2007). The mcrA gene commonly encodes the K-subunit of methyl coenzyme M reductase (MCR), which is the key catabolic enzyme of methanogens (Freitag and Prosser 2009). The pmoA gene, commonly recognized as a phylogenetic marker of methanotrophs in ecological studies, encoding the membranebound subunit of the particulate methane monooxygenase (MMO) (Henckel et al. 1999). Moreover, it is widely accepted that the particulate methane monooxygenase ( vides a molecular indicator of methane oxidation potential (Scheer et al. 2008; Singh et al. 2009). Therefore, the abundance and community compositions of methanogens and methanotrophs could be respectively characterized by the $m c r \mathrm{~A}$ and pmoA genes. Within the last decade, studies on the abundance and community compositions of the methanogens and mehanotrophs under different land-uses have become more common (Bao et al. 2016; Wang et al. 2015). Nevertheless, the changes of the methanogens and methanotrophs induced by land-use conversion from paddies to orchards are scarce. In addtion, researches on the linkage between the relating microorganisms and in situ soil $\mathrm{CH}_{4}$ fluxes remains unclear. Therefore, it is essential to explore the relationships between methanogens, methanotrophs, and soil $\mathrm{CH}_{4}$ fluxes to clarify the underlying mechanism driving the soil-atmosphere exchange of $\mathrm{CH}_{4}$.

China is one of the most important rice-producing countries in the world and the annual $\mathrm{CH}_{4}$ emissions from Chinese rice cultivations are about 7.4 $\mathrm{Tg} \mathrm{CH}_{4} \mathrm{Y}^{-1}$ (Yan et al. 2009). The hilly red soil region is characteristic of typical agricultural soil and covers an area of almost $11.8 \%$ of the country land surface, producing $80 \%$ of the rice, and supporting $22.5 \%$ of China's population (Liu et al. 2016). Over the past few years, this region has undergone great changes in land-uses, in particular the land-use conversion from paddies to uplands for cultivating fruits and economic orchards. These changes in land-uses and fertilization might cause marked variations in the soil $\mathrm{CH}_{4}$ fluxes owing to the alteration in the microbial activity. However, little information is available on the exhaustive assessments of the responses of soil methanogens, and methanotrophs, as well as in situ $\mathrm{CH}_{4}$ fluxes to the landuse conversion and fertilization in the hilly red soil region of southern China. Therefore, the present study aimed to (1) evaluate the effects of land-use conversion and fertilization on soil $\mathrm{CH}_{4}$ fluxes; (2) examine the variations in the abundance and communities of methanogenic archaea and methanotrophic bacteria, with the $m c r \mathrm{~A}$ and $p m o \mathrm{~A}$ gens, respectively; and (3) explore the potential linkages between soil $\mathrm{CH}_{4}$ fluxes and the abundance and communities of methanogens and methanotrophs.

\section{Materials and methods}

\section{Site description and experimental design}

The experiment site was conducted at Qianyanzhou Ecological Research Station of Chinese Academy of Science (CAS) $\left(26^{\circ} 44^{\prime} 46^{\prime \prime} \mathrm{N}, 115^{\circ} 04^{\prime} 05^{\prime \prime} \mathrm{E}\right)$ in Taihe city, Jiangxi province, southern China. According to the meteorological data from 1989 to 2010, this area was characteristic of a subtropical monsoon climate, with an average annual air temperature of $18.0{ }^{\circ} \mathrm{C}$ and precipitation of $1509.0 \mathrm{~mm}$. The soil is typically red soil found in southern China and classified as Cambosols in the Ultisols soil classification.

In the present experiment, the two most common land-uses were selected, namely rice paddy (Oryza sativa L.) and citrus orchard (Citrus reticulata L.). The paddy fields had been continuously cultivated for approximately 10 years and a portion of the fields has been converted to orchard plots in June 2012. Meanwhile, in order to evaluate fertilization effects, fertilization and non-fertilization treatments were established under the two land-uses. Therefore, four treatments with four replicates were employed, referred as citrus orchard with fertilization (OF), citrus orchard without fertilization (ONF), rice paddy with fertilization $(\mathrm{PF})$, and rice paddy without fertilization 
(PNF). The planting density was $235,000 \mathrm{ha}^{-1}$ and the spacing was $0.25 \times 0.17 \mathrm{~m}$ in the paddy plots, whereas the converted orchards were planted at a planting density of 833 plants ha ${ }^{-1}$ with a spacing of $3 \times 4 \mathrm{~m}$. Under the two land-uses, fertilizer was evenly sprinkled over the soil surface. The details about the management in the orchards and paddies were described in our early studies (Liu et al. 2016). These fertilization systems, fertilizer rates, and plant population were chosen according to common experiences from local farmers. The detailed description about the intensive cultivations and fertilization managements during our observing period are given in Table 1.

\section{Field soil $\mathrm{CH}_{4}$ fluxes measurements}

The exchanges of $\mathrm{CH}_{4}$ fluxes between soil and atmosphere from Aug 2013 to Jul 2014 were measured using static chamber and gas chromatography technology. The chambers were made of stainless steel materials and comprise two separate sections: a cylindrical base frame and a chamber. The base frames (a bottom area of $0.12 \mathrm{~m}^{2}$ ) without covering the vegetation were installed at depth of $0.05 \mathrm{~m}$ in all plots several days before the initial sampling and kept in the places marked. The chambers had a bottom area of $0.12 \mathrm{~m}^{2}$ and heights of $0.39 \mathrm{~m}$ (used for orchards) and $0.69 \mathrm{~m}$ (used for paddies), respectively. During the gas sampling, chambers were temporarily mounted onto the base frames. All gases were sampled in the 09:00-11:00 a.m. The gas samples were collected daily for 4 days after fertilization and once or twice per week for the remainder of the time. The gases were taken with $100 \mathrm{ml}$ plastic syringes at $0,10,20,30$, and $40 \mathrm{~min}$ after the chamber was closed. Within $24 \mathrm{~h}$ after gas collection, the $\mathrm{CH}_{4}$ concentrations of the gas samples were measured using gas chromatography (Agilent 7890A, Santa Clara, California, USA). Then, the soil $\mathrm{CH}_{4}$ fluxes were computed on the basis of the rate of variations of $\mathrm{CH}_{4}$ concentrations in the chambers, and calculated as the slope of linear or nonlinear regression between concentrations and time. During gas sampling, the temperature of the chamber was recorded using a portable thermometer and then used to calibrate the actual gases concentrations.

\section{Soil sampling and chemical analysis}

During Aug 2013 and Jul 2014, soil samples from the top layer $(0-10 \mathrm{~cm})$ were sampled once per month or once in every 2 months. In each plot, five soil cores (diameter $=3 \mathrm{~cm}$ ) were randomly collected and combined together. Then, each bulk soil sample was removed with stones and other materials. After that, the composite soil samples were trisected: the first section was air-dried to analyze soil organic carbon (SOC), total nitrogen (TN), $\mathrm{C}: \mathrm{N}$ ratio, and $\mathrm{pH}$; the second section was restored at $-20{ }^{\circ} \mathrm{C}$ for analysis of soil ammonia $\left(\mathrm{NH}_{4}{ }^{+}-\mathrm{N}\right)$ and dissolved carbon (DOC) contents, and the remaining section was freezedried and restored at $-80{ }^{\circ} \mathrm{C}$ for molecular analysis.

Daily air temperature and precipitation were recorded by the climate station located in this region. Soil temperature and moisture were measured using an automatic data recording system via wireless technology. The $\mathrm{pH}$ was measured by a $\mathrm{pH}$ meter. Soil SOC, TN, and $\mathrm{C}: \mathrm{N}$ ratio were determined by an element analyzer (Elementar, Hanau, Germany). For the DOC contents, $20 \mathrm{~g}$ of soil was extracted by adding $0.1 \mathrm{~L}$ distilled water; after that, the admixture was shaken for $1 \mathrm{~h}$, and filtered, and assessed with a TOC-TN analyzer (Elementar,
Table 1 Description of management practices used for the paddy and orchard

\begin{tabular}{|c|c|c|}
\hline Land use & Management & Date \\
\hline \multirow[t]{2}{*}{ Orchard } & $\begin{array}{l}\text { Compound fertilizer }\left(67.2 \mathrm{~kg} \mathrm{~N} \mathrm{ha}^{-1}\right) \\
\text { and urea } \\
\left(20.8 \mathrm{~kg} \mathrm{~N} \mathrm{ha}^{-1}\right) \\
\text { were applied to the fertilization treatment }\end{array}$ & Jul 17, 2013 \\
\hline & $\begin{array}{l}\text { Compound fertilizer }\left(67.2 \mathrm{~kg} \mathrm{~N} \mathrm{ha}^{-1}\right) \text { and urea } \\
\left(20.8 \mathrm{~kg} \mathrm{~N} \mathrm{ha}^{-1}\right) \text { were applied to the } \\
\text { fertilization treatment }\end{array}$ & Apr 17, 2014 \\
\hline \multirow[t]{6}{*}{ Paddy } & $\begin{array}{l}\text { Rice transplanting and compound fertilizer } \\
\left(72 \mathrm{~kg} \mathrm{~N} \mathrm{ha}^{-1}\right) \text { were applied to the } \\
\text { fertilization treatment }\end{array}$ & Jul 30, 2013 \\
\hline & $\begin{array}{l}\text { Urea }\left(106 \mathrm{~kg} \mathrm{~N} \mathrm{ha}^{-1}\right) \text { was applied to the } \\
\text { fertilization treatment }\end{array}$ & Aug 10, 2013 \\
\hline & Rice harvest & Nov 14, 2013 \\
\hline & $\begin{array}{l}\text { Rice transplanting and compound fertilizer } \\
\left(72 \mathrm{~kg} \mathrm{~N} \mathrm{ha}^{-1}\right) \text { were applied to the } \\
\text { fertilization treatment }\end{array}$ & Apr 19, 2014 \\
\hline & $\begin{array}{l}\text { Urea }\left(106 \mathrm{~kg} \mathrm{~N} \mathrm{ha}^{-1}\right) \text { was applied to the } \\
\text { fertilization treatment }\end{array}$ & Apr 29, 2014 \\
\hline & Rice harvest & Jul 22, 2014 \\
\hline
\end{tabular}


Laurel, NJ). Soil $\mathrm{NH}_{4}{ }^{+}-\mathrm{N}$ contents were analyzed with a flowinjection auto analyzer (Seal AA3, Norderstedt, Germany).

\section{DNA extraction and quantitative real-time PCR}

Soil DNA was extracted from freeze-dried bulk soil $(0.3 \mathrm{~g})$ using the Mobio Powersoil ${ }^{\mathrm{TM}}$ DNA isolation kit (MoBio Laboratories Inc., Carlsbad, CA, USA). The concentration and quality of the extraction was checked by a NanoDrop ND-1000 spectrophotometer (NanoDrop Technologies, Wilmington, DE, USA). All the soil DNA extracts were diluted with nuclease-free DI water (DNA: water $=1: 5)$ to reduce potential PCR inhibition and preserved at $-80{ }^{\circ} \mathrm{C}$.

Quantitative real-time PCR (qPCR) was applied to quantified the copy numbers of methanogenic mcrA gene (primer set ME1 (GCMATGCARATHGGWATGTC)/ME2 (TCATKGCRTAGTTDGGRTAGT)) (Hales et al. 1996) and methanotrophic pmoA gene (primer set A189F (GGN GAC TGG GAC TTC TGG)/mb661 (CCG GMG CAA CGT CYT TAC C)) (McDonald et al. 2008). The copy numbers were determined by qPCR using an iCycler iQ2 Thermocycler (Bio-Rad Laboratories, Hercules, CA, USA). All the DNA samples were run in triplicates in a final volume of $25 \mu \mathrm{l}$ reaction system containing $12.5 \mu \mathrm{l}$ of SYBR ${ }^{\circledR}$ Premix Ex Taq ${ }^{\mathrm{TM}}$ (TaKaRa Biotechnology, Dalian, China), $0.5 \mu \mathrm{l}$ of each primer $(10 \mu \mathrm{M}), 2 \mu \mathrm{l}$ of the diluted DNA (1-10 ng) and $9.5 \mu \mathrm{l}$ of nuclease-free DI water. In order to generate a standard curve, individual clones with accurate inserts were cultured in LuriaBertani medium and the plasmid DNA was extracted, purified, and quantified. Plasmid DNA was prepared in a 10fold dilution series to yield a standard curve covering six orders of magnitude $\left(10^{2}\right.$ to $10^{8}$ copies $)$ per assay. The qPCR amplification efficiencies were in the range of 95$100 \%$, and the $R^{2}$ was $0.995-0.998$. Besides, dissociation curves and gel electrophoresis were employed to confirm whether the amplified DNA fragments were of correct size. The final copies of the methanogenic archaea and methanotrophic bacteria were determined by calculation against the plasmid DNA copies.

\section{Terminal restriction fragment length polymorphism (TRFLP), cloning, and sequence analysis}

The methanogen and methanotroph community compositions were determined using soil samples collected in Jul 2014. The PCR amplification was carried out with the same primer pairs as those used for qPCR assays, with the forward primers being labeled with 6-carboxyfluorescein. Then, the PCR products obtained were purified by the PCR purification kit (Promega, San Luis Obispo, USA). Subsequently, the fluorescent-labeled PCR products were digested using the restriction enzymes Eco311 and MspI (Takara Biotechnology, Dalian, China), respectively, for the $m c r A$ and pmoA gene products at $37^{\circ} \mathrm{C}$ for $3 \mathrm{~h}$, followed by inactivation at $65^{\circ} \mathrm{C}$ for $20 \mathrm{~min}$. The digests were purified by ethanol precipitation and re-suspended in $20 \mu \mathrm{l}$ of water. Then, $10 \mu \mathrm{l}$ of the digest were mixed with $15 \mu \mathrm{l}$ of HiDiformamide and $0.3 \mu \mathrm{l}$ of internal DNA fragment length standard (Applied Biosystems). The terminal restriction fragments (T-RFs) were calculated with the GeneMarker software package (version 2.2.0). The relative high abundance TRFs $(>1 \%)$, which fell in the range of $0-500 \mathrm{bp}$, were employed for analysis.

Two clone libraries were acquired using the $m c r \mathrm{~A}$ and pmoA gene fragments retrieved from the PNF and ONF treatments, respectively. The primers used for PCR amplification were the same as those employed earlier but not fluorescent labeled. The purified PCR products were ligated with pGEMT Easy Vector (Promega, Madison, WI, USA) and transformed into Escherichia coli JM109 cells (Takara Biotechnology, Dalian, China). Subsequently, approximately 50 clones were chosen randomly and sequenced with an $\mathrm{ABI}$ 3730 sequencer (Applied Biosystems). Then high-quality sequences were compared to the genes in the NCBI database and examined for chimeras manually, and sequences with alignment splits were removed. The sequences were aligned and two phylogenetic trees were acquired with neighborjoining tree analysis (1000 bootstrap replicates) by MEGA 6 software (Tamura et al., 2013). To match every clone with a particular T-RF, the sequences acquired were run in REMA software to determine the size of the T-RF (Szubert et al. 2007). The whole sequences acquired in our work were submitted to the GenBank database with the following accession numbers: KX130584-KX130599 for the mcrA gene, and KX077180-KX077192 and KX130600 for the pmoA gene.

\section{Statistical analyses}

Repeated measures ANOVA were applied to examine the differences in soil properties, abundance of $m c r A$ and pmoA genes, and $\mathrm{CH}_{4}$ fluxes among the four treatments. Repeated measures ANOVA were also conducted to examine the effects of land-use conversion, fertilization as well as their interactions on soil properties, abundance of $m c r \mathrm{~A}$ and $p m o \mathrm{~A}$ genes, and $\mathrm{CH}_{4}$ fluxes. Regression and multiple regression analyses were employed to examine the relationships among $\mathrm{CH}_{4}$ fluxes, abundance of $m c r \mathrm{~A}$ and pmoA genes, and soil properties. All the statistical analyses were performed using the SPSS software (SPSS Inc., Chicago, IL, USA). Redundancy analysis (RDA) of the T-RFLP profiles was performed to summarize the variations in the methanogen and methanotroph communities that could definitely be explained by the soil properties using CANOCO software (Microcomputer Power, Ithaca, NY, USA). 


\section{Results}

\section{Soil properties}

The soil moisture of the paddy plots was greater than that of the orchards, while the reverse patterns were observed for soil temperature (Table 2). Both land-use conversion and fertilization distinctly reduced soil $\mathrm{pH}(P<0.001)$, with the lowest $\mathrm{pH}$ being detected in the $\mathrm{OF}$ treatment (Table 2). Moreover, landuse conversion from paddies to orchards distinctly increased the SOC contents, TN contents, and C:N ratio (Table 2, $P<0.05)$. Fertilization did not affect soil moisture, soil temperature, $\mathrm{SOC}$, and $\mathrm{C}: \mathrm{N}$ ratio under the orchards and paddies (Table 2, $P>0.05$ ). Soil TN contents were affected by fertilization (Table $2, P<0.05$ ). The soil DOC contents were significantly lower in the orchard plots when compared with those in the paddy fields (Table 2). Fertilization significantly affect the soil DOC contents (Table $2, P<0.05$ ). In addition, fertilization significantly increased soil $\mathrm{NH}_{4}{ }^{+}-\mathrm{N}$ contents, when compared with unfertilized plots (Table $2, P<0.05$ ).

\section{Environmental conditions and soil $\mathrm{CH}_{4}$ fluxes}

The annual precipitation was $1424.8 \mathrm{~mm}$, which is below than the long-term average $(1509.0 \mathrm{~mm})$. Rainfall between March and June accounted for $57 \%$ of the annual precipitation, with the largest and smallest monthly rainfall occurring in May and February, respectively (Fig. 1a). The average annual air temperature was $19.3^{\circ} \mathrm{C}$, with maximum and minimum daily air temperature being $31.9{ }^{\circ} \mathrm{C}$ (August 2013) and $0.02{ }^{\circ} \mathrm{C}$ (February 2014), respectively (Fig. 1a).

The amounts and patterns of $\mathrm{CH}_{4}$ fluxes were significantly different between the two land-uses (Fig. 1b, c). The $\mathrm{CH}_{4}$ emission fluxes from the conventional paddy plots exhibited distinct seasonal variations, peaked at almost 20 days after flooding and declined and became stabilized on the day before harvest (Fig. 1c). In the converted orchard plots, most of the $\mathrm{CH}_{4}$ exchange fluxes were negative and higher amounts of $\mathrm{CH}_{4}$ were oxidized in summer when the soil moisture was moderate and temperature was higher (Fig. 1a, b). The average $\mathrm{CH}_{4}$ fluxes for the paddy fields were significantly greater than those for the orchard plots during the observation period (Table 3, $P<0.05$ ). However, the average soil $\mathrm{CH}_{4}$ flux between unfertilized and fertilized treatment were not significantly different under the orchard plots and paddy field (Table 3, $P>0.05$ ).

\section{Abundance of methanogens and methanotrophs}

The $m c r$ A copy numbers ranged from $2.55 \times 10^{6}$ to $2.53 \times 10^{7}$ and from $2.26 \times 10^{6}$ to $6.40 \times 10^{7}$ copies $\mathrm{g}^{-1}$ dry soil, while the pmoA copy numbers ranged from $1.42 \times 10^{5}$ to $4.95 \times 10^{5}$ and from $4.81 \times 10^{5}$ to $4.76 \times 10^{6}$ copies $^{-1}$ dry soil in the orchard and paddy soils, respectively (Fig. 2a, b). As for the paddy fields, the mcrA copy numbers were highest in June 2014, whereas maximum pmoA copy numbers were observed in November 2013 (Fig. 2a, b). In the orchard plots, the highest $m c r \mathrm{~A}$ and $p m o \mathrm{~A}$ abundance were noted in May 2014 and June 2014, respectively (Fig. 2a, b). Furthermore, the $m c r \mathrm{~A}$ and $p m o \mathrm{~A}$ abundance was statistically different between the land-uses, with lower mean $m c r \mathrm{~A}$ and pmoA abundance detected in orchard plots, irrespective of the fertilization treatment (Table 3). However, although the fertilization treatment showed lower mcrA and pmoA abundance when compared with the non-fertilization treatment in both orchard and paddy plots, the difference between them was not statistically significant (Table 3).

Table 4 summarizes the relationships among soil $m c r A$ and pmoA abundance and soil properties. For the orchard plots, the coefficients of the best analysis (i.e., $\mathrm{CH}_{4}$ fluxes and $\mathrm{SOC}$

Table 2 Effects of land-use conversion and fertilization on soil properties

\begin{tabular}{|c|c|c|c|c|c|c|c|c|}
\hline Treatment & $\begin{array}{l}\text { Soil moisture } \\
(\%)\end{array}$ & $\begin{array}{l}\text { Soil } \\
\text { temperature } \\
\left({ }^{\circ} \mathrm{C}\right)\end{array}$ & $\mathrm{pH}$ & $\begin{array}{l}\text { SOC } \\
\left(\mathrm{g} \mathrm{kg}^{-1}\right)\end{array}$ & $\begin{array}{l}\mathrm{TN} \\
\left(\mathrm{g} \mathrm{kg}^{-1}\right)\end{array}$ & $\mathrm{C}: \mathrm{N}$ ratio & $\begin{array}{l}\text { DOC } \\
\left(\mathrm{mg} \mathrm{kg}^{-1}\right)\end{array}$ & $\begin{array}{l}\mathrm{NH}_{4}^{+}-\mathrm{N} \\
\left(\mathrm{mg} \mathrm{kg}^{-1}\right)\end{array}$ \\
\hline $\mathrm{OF}$ & $22.74 \pm 0.61 b$ & $23.98 \pm 0.28 \mathrm{a}$ & $4.76 \pm 0.03 d$ & $10.20 \pm 0.54 \mathrm{a}$ & $1.16 \pm 0.05 \mathrm{a}$ & $8.81 \pm 0.11 \mathrm{a}$ & $20.78 \pm 3.12 c$ & $12.65 \pm 1.25 \mathrm{a}$ \\
\hline ONF & $22.14 \pm 0.33 b$ & $23.61 \pm 0.41 \mathrm{a}$ & $4.87 \pm 0.03 c$ & $9.79 \pm 0.52 \mathrm{ab}$ & $1.12 \pm 0.06 \mathrm{ab}$ & $8.72 \pm 0.06 \mathrm{a}$ & $18.25 \pm 2.34 \mathrm{c}$ & $8.33 \pm 0.47 b$ \\
\hline $\mathrm{PF}$ & $36.97 \pm 0.22 \mathrm{a}$ & $21.46 \pm 0.08 b$ & $4.95 \pm 0.03 b$ & $9.02 \pm 0.44 b$ & $1.08 \pm 0.03 b$ & $8.44 \pm 0.12 b$ & $32.44 \pm 1.96 \mathrm{a}$ & $10.89 \pm 0.94 a$ \\
\hline $\mathrm{PNF}$ & $37.17 \pm 0.34 \mathrm{a}$ & $21.63 \pm 0.11 b$ & $5.04 \pm 0.04 \mathrm{a}$ & $9.09 \pm 0.35 b$ & $1.06 \pm 0.03 b$ & $8.50 \pm 0.11 b$ & $29.23 \pm 2.40 b$ & $8.52 \pm 1.07 \mathrm{~b}$ \\
\hline \multicolumn{9}{|l|}{ Significance of } \\
\hline Land-use conversion & 0.000 & 0.021 & 0.000 & 0.013 & 0.000 & 0.005 & 0.000 & 0.055 \\
\hline Fertilization & 0.435 & 0.235 & 0.000 & 0.141 & 0.033 & 0.416 & 0.026 & 0.000 \\
\hline $\begin{array}{l}\text { Land-use conversion } \times \\
\text { fertilization }\end{array}$ & 0.475 & 0.465 & 0.995 & 0.682 & 0.165 & 0.165 & 0.821 & 0.019 \\
\hline
\end{tabular}

Values are means with standard errors. Different letters in the same column indicate significant differences $(P<0.05)$. Significant effects $(P<0.05)$ are highlighted in italics. Treatments are $O F$ orchard with fertilization, $O N F$ orchard without fertilization, $P F$ paddy with fertilization, $P N F$ paddy without fertilization 
Fig. 1 Seasonal variation of the daily air temperature and precipitation (a), and soil $\mathrm{CH}_{4}$ fluxes in the orchard plots (b) and paddy fields (c) during the observation period. The values are means with standard errors. Black arrows indicate the fertilizer applied to OF; gray arrows indicate fertilizer applied to PF. Horizontal bars indicated the period of flooding in the paddy plots. Treatments are $O F$, orchard with fertilization; $O N F$, orchard without fertilization; $P F$, paddy with fertilization; $P N F$, paddy without fertilization

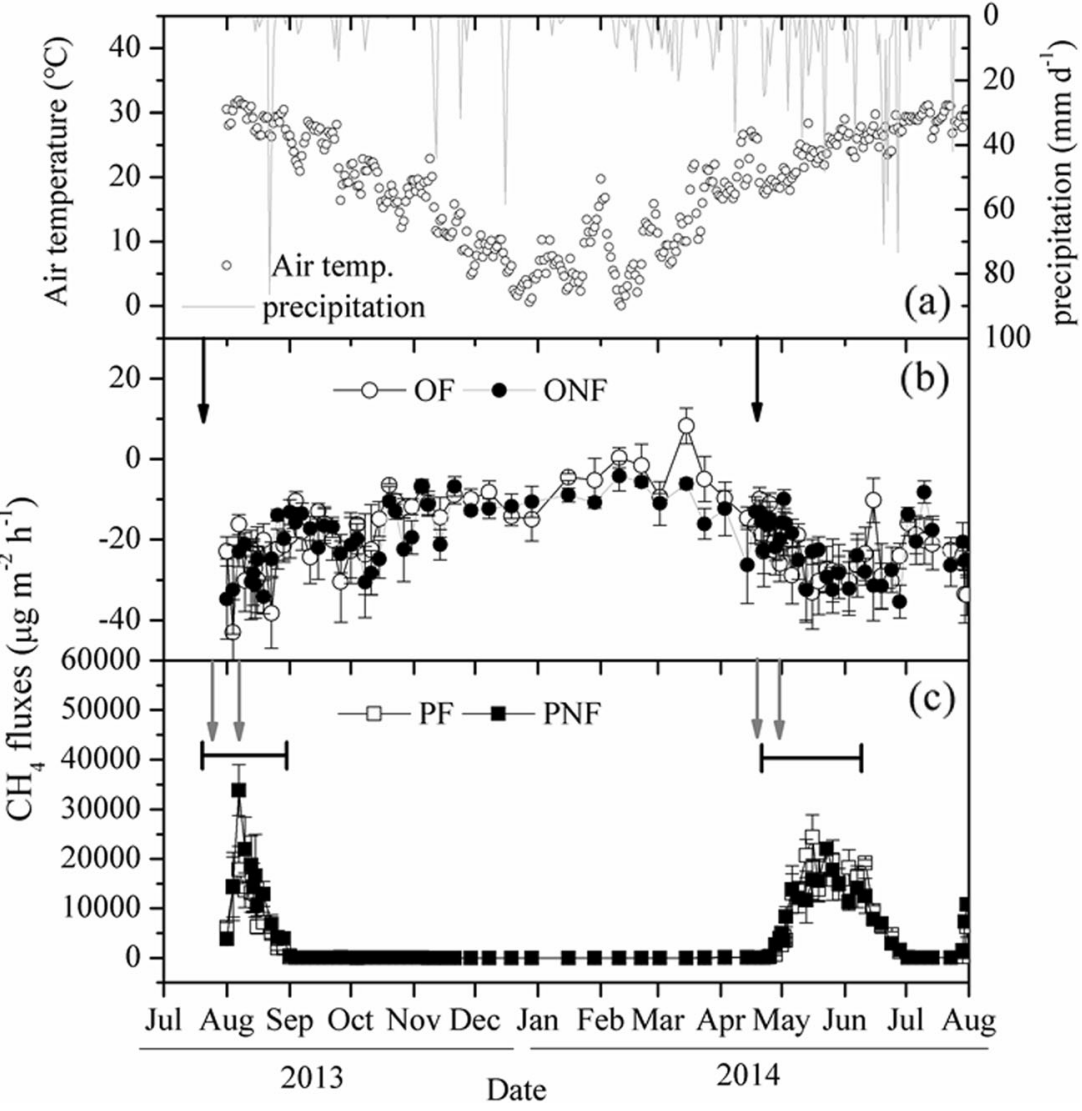

contents) were used in multiple regression study against pmoA abundance, and an $R^{2}$ of 0.57 was obtained. However, no significant correlation between $\mathrm{mcr}$ A abundance and soil properties was observed. For the paddy plots, the best multiple regression result for the pmoA abundance including soil DOC and $\mathrm{CH}_{4}$ fluxes, with an $R^{2}$ of 0.53 , whereas the best fit of soil properties against $m c r \mathrm{~A}$ abundance including soil moisture, $\mathrm{pH}$, and soil temperature, with an $R^{2}$ of 0.86 .

\section{Community structure of methanogens and methanotrophs}

In total, six T-RFs were considered to be main peaks in the TRFLP spectrum of $m c r$ A gene (Fig. 3a). The clone sequences were analyzed to associate the T-RFs with the respective methanogens, which suggested that five T-RFs could be specified to a single lineage, i.e., T-RFs of 97,292 , and 139 bp to Methanosarcina and T-RFs of 195 and 280 bp to Methanocella
Table 3 Effects of land-use conversion and fertilization on mean soil $\mathrm{CH}_{4}$ fluxes, $m c r \mathrm{~A}$, and pmoA abundance

\begin{tabular}{llll}
\hline Treatment & $\begin{array}{l}\mathrm{CH}_{4} \text { fluxes } \\
\left(\mu \mathrm{g} \mathrm{m}^{-2} \mathrm{~h}^{-1}\right)\end{array}$ & $\begin{array}{l}\text { mcrA abundance } \\
(\text { copies g }\end{array}$ & $\begin{array}{l}\text { dry soil }) \\
(\text { copies g abundance }\end{array}$ \\
\hline OF & $-19.12 \pm 4.79 \mathrm{~b}$ & $5.80 \times 10^{6} \pm 9.92 \times 10^{5} \mathrm{~b}$ & $2.50 \times 10^{5} \pm 5.40 \times 10^{4} \mathrm{~b}$ \\
$\mathrm{ONF}$ & $-19.99 \pm 4.47 \mathrm{~b}$ & $8.53 \times 10^{6} \pm 2.61 \times 10^{5} \mathrm{~b}$ & $3.10 \times 10^{5} \pm 7.08 \times 10^{4} \mathrm{~b}$ \\
$\mathrm{PF}$ & $4398.94 \pm 904.36 \mathrm{a}$ & $2.70 \times 10^{7} \pm 5.74 \times 10^{6} \mathrm{a}$ & $1.37 \times 10^{6} \pm 5.74 \times 10^{5} \mathrm{a}$ \\
$\mathrm{PNF}$ & $4855.70 \pm 1238.0 \mathrm{a}$ & $2.90 \times 10^{7} \pm 7.37 \times 10^{6} \mathrm{a}$ & $1.54 \times 10^{6} \pm 6.00 \times 10^{5} \mathrm{a}$ \\
Significance of & & & 0.000 \\
Land-use conversion & 0.000 & 0.000 & 0.431 \\
Fertilization & 0.458 & 0.069 & 0.716 \\
Land-use conversion $\times$ & 0.457 & 0.422 & \\
$\quad$ fertilization & & & \\
\hline
\end{tabular}

Values are means with standard errors. Different letters in the same column indicate significant differences $(P<0.05)$. Significant effects $(P<0.05)$ are highlighted in italics. Treatments are $O F$ orchard with fertilization, $O N F$ orchard without fertilization, $P F$ paddy with fertilization, $P N F$ paddy without fertilization 


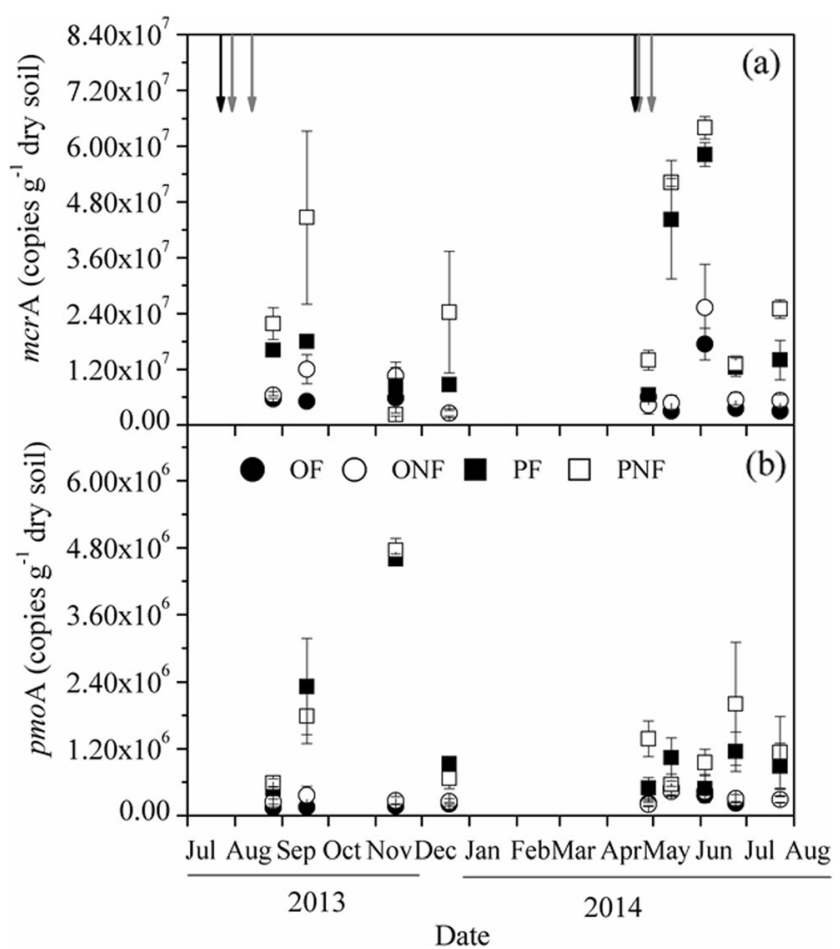

Fig. 2 Seasonal variation of $m c r A$ (a), and pmoA abundance (b) under the four treatments. Values are means with standard errors. Black arrows indicate fertilizer applied to OF; gray arrows indicate fertilizer applied to $\mathrm{PF}$; the arrows in (a) applied to (b). Treatments are $O F$, orchard with fertilization; $O N F$, orchard without fertilization; $P F$, paddy with fertilization; $P N F$, paddy without fertilization

(Fig. S1). However, T-RF of $329 \mathrm{bp}$ was characteristic of Methanosarcina, Methanoregula, and Methanosaeta (Fig. S1). In the orchard plots, members of Methanosarcina and Methanocella were observed (Fig. 3a), whereas in the paddy fields, members of Methanosarcina, Methanocella, Methanoregula, and Methanosaeta were detected (Fig. 3a).
Moreover, the community compositions of methanogens were almost similar between fertilization and non-fertilization treatment under the two land-uses (Fig. 3a).

Seven T-RFs were considered to be main peaks in the T-RFLP profiles for the pmoA gene (Fig. 3b). Four T-RFs were specified to a single lineage, such as T-RF of $130 \mathrm{bp}$ to Methylococcus, T-RF of $13 \mathrm{bp}$ to Methylobacter, and TRFs of 401 and 53 bp to Methylocystis, whereas T-RFs of 19 and $295 \mathrm{bp}$ were assigned to type II methanotrophs (Methylocystis and Methylosinus) (Fig. S2). However, TRF of 76 bp could not be characteristic of any sequences (Fig. S2). In the four treatments, the T-RF of $295 \mathrm{bp}$ showed the highest relative abundance (Fig. $3 \mathrm{~b}$ ). Furthermore, land-use conversion from paddies to orchards reduced type I methanotrophs (Methylococcus and Methylobacter), but increased type II methanotrophs (Methylocystis and Methylosinus) $(P<0.05)$. Moreover, fertilization significantly affected T-RF of 13 bp under the orchard plots $(P<0.05)$.

The RDA analysis was conducted by combing compositions of soil methanogen and methanotroph to show the relationships among soil properties and microbial compositions (Fig. 4). The results showed that the first (RD1) and second (RD2) axes explained 89.8 and $2.3 \%$ of the total variations of the community structures of methanogens and methanotrophs, respectively (Fig. 4) Furthermore, the results indicated that the orchard plots were best characterized by soil temperature, SOC, TN, C:N ratio, and Methylocystis and Methanosarcina, whereas the paddy fields were characterized by soil $\mathrm{CH}_{4}$ fluxes, DOC contents, $\mathrm{pH}$, soil moisture, and Methanoregula, Methanosarcina, Methylobacter, Methanosaeta, Methylosystis. The different cluster of symbols in Fig. 4 indicates that land-use conversion but not of fertilization significantly induced the variation of microbial communities.

Table 4 Multiple regressions among $\mathrm{CH}_{4}$ fluxes, copy numbers of $m c r \mathrm{~A}$ gene and $p m o \mathrm{~A}$ gene, and soil properties

\begin{tabular}{|c|c|c|c|c|}
\hline Land use & Soil fluxes/gene abundance & $\begin{array}{l}\text { Regression } \\
\text { equation }\end{array}$ & $R^{2}$ & $P$ value \\
\hline \multirow[t]{3}{*}{ Orchard } & 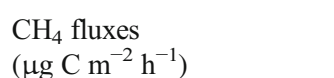 & $y=-10.27-4.44 \times 10^{-5} p m o \mathrm{~A}$ & 0.41 & 0.004 \\
\hline & $\begin{array}{l}\text { pmoA } \\
\text { (copies } \mathrm{g}^{-1} \text { dry soil) }\end{array}$ & $y=4.76 \times 10^{5}-9.23 \times 10^{4} \mathrm{CH}_{4}-4.01 \times 10^{4} \mathrm{SOC}$ & 0.57 & 0.002 \\
\hline & $\begin{array}{l}m c r A \\
\text { (copies } g^{-1} \text { dry soil) }\end{array}$ & - & - & - \\
\hline \multirow[t]{3}{*}{ Paddy } & $\begin{array}{l}\mathrm{CH}_{4} \text { fluxes } \\
\left(\mu \mathrm{g} \mathrm{m}^{-2} \mathrm{~h}^{-1}\right)\end{array}$ & $y=-8.51+5.18 \times 10^{-5} m c r \mathrm{~A}+3.76 \times 10^{2} \mathrm{DOC}$ & 0.84 & 0.000 \\
\hline & $\begin{array}{l}\text { pmoA } \\
{\text { (copies } \mathrm{g}^{-1} \text { dry soil) }}\end{array}$ & $y=4.96 \times 10^{6}-1.43 \times 10^{5} \mathrm{DOC}+2.09 \times 10^{2} \mathrm{CH}_{4}$ & 0.53 & 0.003 \\
\hline & $\begin{array}{l}\text { mcrA } \\
\text { (copies } \mathrm{g}^{-1} \text { dry soil) }\end{array}$ & $y=-2.85 \times 10^{8}+1.37 \times 10^{6} \mathrm{SM}+4.77 \times 10^{7} \mathrm{pH}+8.11 \times 10^{5} \mathrm{ST}$ & 0.86 & 0.000 \\
\hline
\end{tabular}

SOC soil organic carbon contents, DOC soil dissolved carbon contents, $S M$ soil moisture, $S T$ soil temperature 
Fig. 3 Community structures of methanogens and methanotrophs based on T-RFLP analysis targeting $m c r \mathrm{~A}$ (a) and pmoA (b) genes in the four treatments. Values are means with standard errors. Treatments are $O F$, orchard with fertilization; $O N F$, orchard without fertilization; $P F$, paddy with fertilization; $P N F$, paddy without fertilization (a)

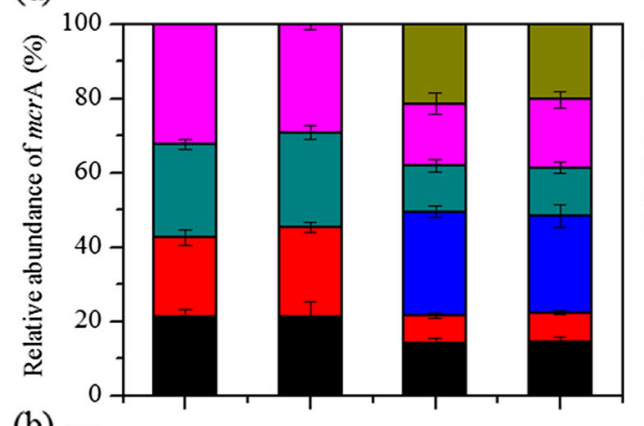

$\square 329$ bp, Methanosarcina/Methanoregula/ Methanosaeta

$\square 292$ bp, Methanosarcina

$\square 280$ bp, Methanocella

195 bp, Methanocella

$\square 139$ bp, Methanosarcina

$97 \mathrm{bp}$, Methanosarcina

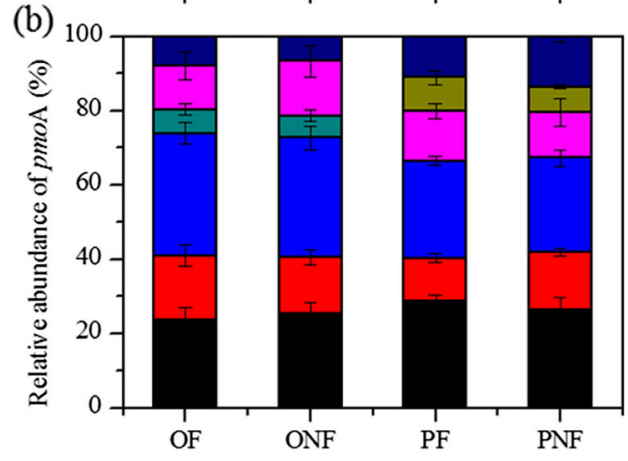

$130 \mathrm{bp}$, Methylococcus

$13 \mathrm{bp}$, Methylobacter

$19 \mathrm{bp}$, Methylocystis/Methylosinus

401 bp, Methylocystis

295 bp, Methylocystis/Methylosinus

76 bp, Unidentify

$53 \mathrm{bp}$, Methylocystis

\section{Correlations between $\mathrm{CH}_{4}$ fluxes and various variables}

In the orchard plots, soil $\mathrm{CH}_{4}$ fluxes could not be fitted to $m c r \mathrm{~A}$ abundance (Fig. 5a), but were negatively correlated with pmoA abundance (Fig. 5b). Meanwhile, the relationships between soil $\mathrm{CH}_{4}$ fluxes and mcrA:pmoA ratio well fitted the quadratic equations (Fig. $5 \mathrm{c}$ ). In the paddy plots, the relationship between $\mathrm{CH}_{4}$ fluxes and mcrA abundance and mcrA:pmoA ratio fitted the linear equations (Fig. $5 \mathrm{~d}$, f). The multiple regression analysis confirmed the correlations between $\mathrm{CH}_{4}$ uptakes and pmoA abundance in the orchards (Table 4). Meanwhile, the DOC contents and mcrA abundance were the main factors controlling soil $\mathrm{CH}_{4}$ fluxes from the paddies (Table 4).

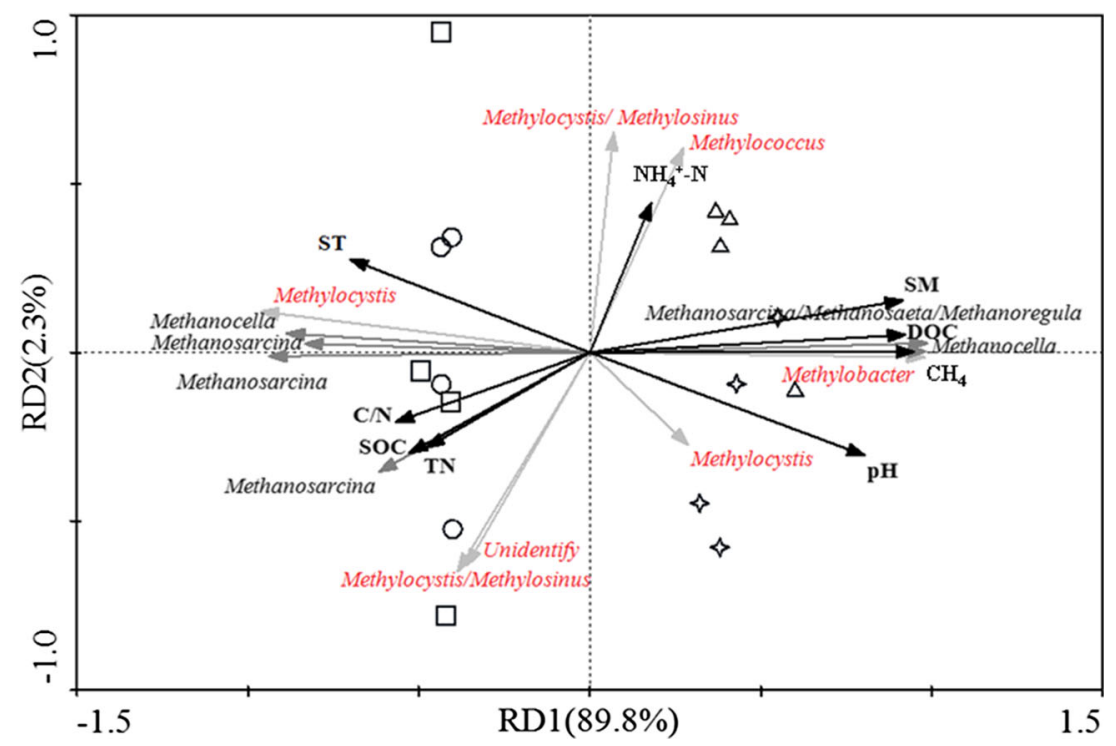

Fig. 4 RDA showing the relationships among land-uses (symbols), soil properties (black vectors), and relative abundance of methanogens (gray vectors) and methanotrophs (light gray vectors). The data are shown for four different land uses, namely, orchard with fertilization (circles); orchard without fertilization (square); paddy with fertilization (triangles); and paddy without fertilization (stars). SOC soil organic carbon contents, $D O C$ soil dissolved carbon contents, $S M$ soil moisture, $S T$ soil temperature, $T N$ total nitrogen contents, $C / N$ C:N ratio 
Fig. 5 Relationships between soil $\mathrm{CH}_{4}$ fluxes and $m c r \mathrm{~A}$ abundance, pmoA abundance, and $m c r$ A:pmoA ratio in orchard plots $(\mathbf{a}-\mathbf{c})$ and paddy fields $(\mathbf{d}-\mathbf{f})$
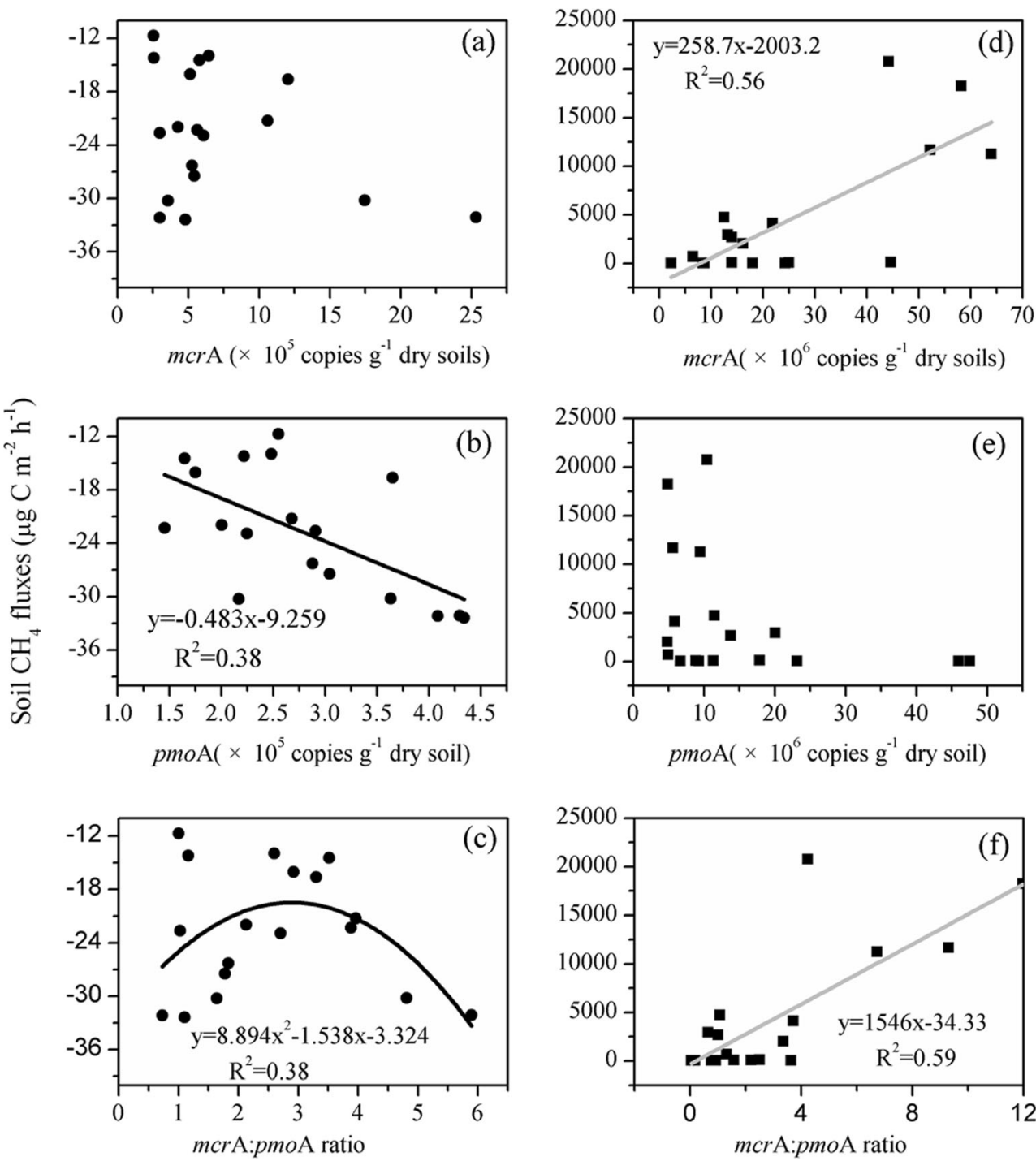

\section{Discussion}

\section{Soil $\mathrm{CH}_{4}$ fluxes}

The seasonal variations of soil $\mathrm{CH}_{4}$ flux in this study exhibited similar patterns to those documented in the paddy fields and upland plots (Eusufzai et al. 2010; Wang et al. 2015). The paddy fields showed higher $\mathrm{CH}_{4}$ fluxes than those from orchard plots, especially in the flooding period (Fig. 1b, c), which was consistent with the argument that drainage would bring about the disappearance of $\mathrm{CH}_{4}$ emissions but appearance of $\mathrm{CH}_{4}$ uptakes (Jäckel et al. 2001; Nishimura et al. 2008). It is noteworthy that several reasons might contribute to the reduced $\mathrm{CH}_{4}$ emissions induced by such land-use conversion. First, $\mathrm{CH}_{4}$ emissions could have probably been caused by anaerobic soil conditions induced by flooding depth on soil surface (data are not shown). It has been reported that longer period of flooding in paddy fields significantly leads to anaerobic soil conditions, in contrast to the aerobic soil condition in upland orchard fields (Inubushi et al. 2003; Nishimura et al. 2008). Second, soil DOC is an important parameter of $\mathrm{CH}_{4}$ emissions from paddy soils because the available carbon substrates supply energy sources and consequently enhance methanogenic activity (Zou et al. 2005; Liu et al. 2015b). According to the common experiences, some crop residue was typically incorporated in the paddies, which would result in more soil DOC contents (Table 2). Lastly, land-use conversion could markedly influence the abundance and community structures of methanogens and methanotrophs, thus determining the soil $\mathrm{CH}_{4}$ fluxes (Jäckel et al. 2001; Liu et al. 2015a). From the microbiological point, $\mathrm{CH}_{4}$ fluxes are largely determined by methanogenic archaea and methanotrophic bacteria. Therefore, changes in the $\mathrm{CH}_{4}$ fluxes induced by land-use conversion or fertilization would 
be inherently caused by the responses of these two functional groups. In the following paragraphs, we will illuminate how these factors affect the soil $\mathrm{CH}_{4}$ fluxes.

Although fertilization could reduce $\mathrm{CH}_{4}$ fluxes in some cases (Liu et al. 2016; Zhou et al. 2016), it might increase or fail to affect soil $\mathrm{CH}_{4}$ fluxes depending on the fertilizer rate (Fan et al. 2016; Reay and Nedwell 2004; Wang et al. 2015). As it is well known that various factors lead to the controversial response of soil $\mathrm{CH}_{4}$ fluxes induced by fertilization. On the one hand, an increase in denitrification intermediates $\left(\mathrm{N}_{2} \mathrm{O}, \mathrm{NO}, \mathrm{NO}_{2}{ }^{-}\right)$induced by fertilization can inhibit methanogens (Bao et al. 2016). On the other hand, $\mathrm{NH}_{4}{ }^{+}$ could suppress $\mathrm{CH}_{4}$ oxidation by binding to the particulate methane monooxygenase and reacting with it (Schimel 2000). Nevertheless, nitrogen fertilizers were shown to be advantageous for the growth of methanogens and some methane-oxidizing bacteria (Bodelier et al. 2000; Lu and Conrad 2005). In this study, fertilization did not significantly affect the abundance of $m c r \mathrm{~A}$ and pmoA gene (Table 3), which might be explained by that the inhibiting and stimulating effects of fertilization on the methanogens and methanotrophs were almost equal. Similarly, Dan et al. (2001) proposed that fertilization stimulated both $\mathrm{CH}_{4}$ production and $\mathrm{CH}_{4}$ oxidation, resulting in no significant effect on $\mathrm{CH}_{4}$ fluxes.

\section{Abundance and community compositions of methanogens and methanotrophs}

In the present study, the abundance of methanogens was significantly lower in the orchard plots than that in the paddy plots (Table 3), which means that land-use conversion from paddies to orchards decreased the abundance of methanogenic archaea. Recently, Liu et al. (2015a) also observed significant decreases in the abundance of methanogens as a result of a relatively lengthy duration of upland conditions in the field study. However, methanogens have been shown to survive well without any distinctive changes in the copy numbers under upland crop cultivation for 7 months (Ma and $\mathrm{Lu}$ 2011). These findings together confirmed our previous results that soils were $\mathrm{CH}_{4}$ emissions sources in the early days after land-use conversion from paddies to orchards, and became $\mathrm{CH}_{4}$ uptakes in the second conversion stage (Liu et al. 2016). Nevertheless, the results on the existence of methanogenic archaea in upland plots are highly controversial (Angel et al. 2012; Hu et al. 2013; Lammel et al. 2015). In our results, methanogenic archaea were detected in the newly converted orchard plots ( 1 year). A possible explanation might be that the presence of detoxification enzymes, such as superoxide dismutase and catalase in some members of methanogens, defended them from harmful products derived from oxygen (Brioukhanov et al. 2000). Therefore, a long-term study on the abundance of methanogenic archaea in an age-sequence of converted orchards should be conducted to clearly show how long they would be survived after land-use conversion from paddies to orchards.

The abundance of methanotrophs in the orchard plots was expected to be higher than that in the paddy fields, as that methanotrophs were considered to be more common in upland fields (Singh et al. 2009; Wang et al. 2015; Lammel et al. 2015). Surprisingly, the abundance of methanotrophs was decreased after land-use conversion from paddies to orchards (Table 3), demonstrating that the abundance of methanotrophs was actively increased in the paddy plots. These results of no significant increases in the methanotrophs abundance in orchard plots were in well agreement with those stated by Jaatinen et al. (2004) who observed higher $\mathrm{CH}_{4}$ oxidizing potential in a Finnish mire than in a well-drained soil. Similarly, Mohanty et al. (2016) also proved that methanotrophs were generally activated at high $\mathrm{CH}_{4}$ concentrations in the culture experiment. Moreover, the significant positive correlations between pmoA abundance and $\mathrm{CH}_{4}$ fluxes in paddy plots confirmed the stimulation of pmoA by $\mathrm{CH}_{4}$ concentrations in the paddy soils (Table 4). Furthermore, although the abundance of $m c r \mathrm{~A}$ and pmoA differed with time, there was no clear response to fertilization at subsequent "pre-fertilization" date (Fig. 2a, b), because our sampling time was not at each "fertilization" date. These variations across time suggested that temporal dynamics were more important in structuring the microbial processes in the study site.

Our study showed that Methanosarcina and Methanocella were observed in the orchard plots and paddy fields, whereas Methanosaeta and Methanoregula were just detected in the paddy fields (Fig. 3a). Those results suggested that land-use conversion from paddies to orchards resulted in a rather poor diversity of methanogens, which were in well agreement with the statement of former results (Liu et al. 2015a; Scavino et al. 2013). Generally, Methanosarcina and Methanocella were the most abundant methanogens in paddy fields, probably due to their tolerance to oxygen (Angel et al. 2011). However, methanogens belonging to the family Methanosarcina were also detected in the orchard plots owing to their ability to utilize a range of different precursors for methanogenesis (Jetten et al. 1990). Methanocella were known for their ability to withstand toxic oxygen populations (Erkel et al. 2006), which made them better adapted to both paddy and orchard soils (Fig. 3a). In addition, it has been reported that a relatively shorter period of drainage of 7 months may be less harmful to the methanogen community structure ( $\mathrm{Ma}$ and $\mathrm{Lu} 2011$ ). Fertilization were shown to have no significant effects on the community compositions of methanogens, which corresponded well with the results of Ho et al. (2016) who proposed the theory of site history and the "resting" community.

Land-use conversion increased type II methanotrophs (i.e., Methylocystis and Methylosinus), and decreased type I 
methanotrophs (i.e. Methylobacter and Methylococcus) (Fig. 3b). In a study on three land-use types, the community compositions of methanotrophic bacterial were observed to be strongly affected by land-use changes (Zheng et al. 2010). Former studies on the field study indicated that the methanogen communities did not change in the fallow period of rice paddies (Krüger et al. 2005; Ma and Lu 2011). However, there was no field observation on the methanotrophs community induced by land-use conversion from paddies to orchards, thus more studies are urgently needed. In general, soil properties select particular groups of microorganisms potentially by shaping the ecological niches such as substrates concentration and soil properties of the targeted microorganisms (Fig. 4). In addition, although fertilization was found to decrease the T-RF of $13 \mathrm{bp}$ in the orchard plots, no consistent patterns could be generalized with respect to the effects of fertilization on methanotrophs (Alam and Jia 2012).

\section{Correlations between soil $\mathrm{CH}_{4}$ fluxes and methanogens and methanotrophs}

The conventional explanation for soil $\mathrm{CH}_{4}$ fluxes induced by land-use conversion included soil condition and physical properties (Inubushi et al. 2003; Nishimura et al. 2008). In the present study, soil $\mathrm{CH}_{4}$ fluxes were significantly related to the abundance of $m c r A$ and soil DOC contents (Table 4), indicating that $\mathrm{CH}_{4}$ production and carbon substrates were directly related to the $\mathrm{CH}_{4}$ emissions from paddy soils. Meanwhile, mcrA and pmoA genes play an obvious mechanistic role in the actual $\mathrm{CH}_{4}$ fluxes from paddy soils (Lee et al. 2014), as that significant positive relationships between $\mathrm{CH}_{4}$ fluxes and $m c r \mathrm{~A} / \mathrm{pmoA}$ were observed (Fig. 5f). Moreover, it is well known that most of the methanogens could utilize $\mathrm{H}_{2} /$ $\mathrm{CO}_{2}$ for $\mathrm{CH}_{4}$ production, while Methanosaeta can utilize acetate (Metje and Frenzel 2007). Furthermore, Methanosaeta have been described as slow-growing microorganisms and have a much lower acetate threshold (Jetten et al. 1990). In general, $\mathrm{CH}_{4}$ productions from acetate are much higher (typically $67 \%$ ) than those from $\mathrm{H}_{2} / \mathrm{CO}_{2}$ (generally $33 \%$ ) (Metje and Frenzel 2007). Thus, in the present study, the survival of Methanosaeta in the paddy plots might have resulted in more $\mathrm{CH}_{4}$ emissions, which might be an alternative explanation for more $\mathrm{CH}_{4}$ fluxes from paddy soils.

Intuitively, the potential $\mathrm{CH}_{4}$ uptakes in the uplands can be attributed to the stimulation of methanotrophs. Though abundance of methanotrophic bacteria was decreased after land-use conversion (Table 3), the soil $\mathrm{CH}_{4}$ uptakes of orchard plots were negatively correlated with the pmoA abundance (Fig. 5b). The result suggested that pmoA abundance could dominate soil $\mathrm{CH}_{4}$ uptakes in the upland plots, which was in line with former studies (Singh et al. 2009; Wang et al. 2015). Moreover, despite the pmoA abundance decreased (Table 3), the type II methanotrophs increased in the orchard plots (Fig. 3b), which could result in the $\mathrm{CH}_{4}$ uptakes. Singh and Tate (2007) also reported that samples of forest soil, where type II methanotrophs were predominant, were at least 10 times more efficient in oxidizing $\mathrm{CH}_{4}$ than those of pasture soil in which type I methanotrophs were predominant. Thus, effective $\mathrm{CH}_{4}$ oxidation induced by land-use conversion from paddies to orchards could be owing to the significant stimulation of type II methanotrophs. Moreover, it was suggested that type I methanotrophs participated in $\mathrm{CH}_{4}$ consumption only from $50 \mathrm{ppmv}$ methane upward, whereas type II methanotrophs consumed at lower methane concentrations (Knief et al. 2006). Therefore, we could speculate that the methanotrophs of paddy soils mainly oxidized the soil $\mathrm{CH}_{4}$ productions, and those in the orchard soils consumed the atmospheric $\mathrm{CH}_{4}$. In addition, it has been reported that fertilization did not affect $\mathrm{CH}_{4}$ consumptions of the soil where type I methanotrophs predominant, but inhibits $\mathrm{CH}_{4}$ uptakes in the soil predominantly comprising type II methanotrophs (Mohanty et al. 2006). Conversely, in the present study, the soil was clearly dominated by type II methanotrophs, the $\mathrm{CH}_{4}$ consumption was not inhibited by fertilization, as some others reported that a few methanotrophs genera are shown to be able to withstand nitrogen species (Noll et al. 2008).

\section{Conclusion}

Taken together, our results suggested that land-use conversion from paddies to orchards change soils from emission sources to sink of atmospheric $\mathrm{CH}_{4}$, whereas fertilization did not significantly affect soil $\mathrm{CH}_{4}$ fluxes under the two land-uses. The conversion of paddies to orchards decreased the abundance of methanogens and methanotrophs, resulted in poor diversity of methanogens community, and increased type II methanotrophs. The higher $\mathrm{CH}_{4}$ emissions from paddy soils could mainly attribute to the increased soil DOC contents, more methanogens, and compositions of methanogenic archaea. The compositions of methanotrophs and soil conditions together drive the ability of oxidizing atmosphere $\mathrm{CH}_{4}$ of orchard soils. Moreover, no distinct changes in methanogens and methanotrophs could help to explain the stable response of $\mathrm{CH}_{4}$ fluxes to fertilization. Overall, we provide a certain extent evidence of microbial mechanisms for the soil $\mathrm{CH}_{4}$ fluxes induced by land-use conversion and fertilization. Moreover, the findings of $\mathrm{CH}_{4}$ fluxes and dynamics of methanogens and methanotrophs following land-use conversion and fertilization could provide new insights into the soil carbon biogeochemical cycles in red soils.

Acknowledgements This work was supported by the National Natural Science Foundation of China (41471095) and the Ministry of Science and Technology of China (2012CB417103). We would like to thank the staffs 
of the Qianyanzhou Experimental Station for their fruitful assistance in field sampling. Special thanks go to the anonymous reviewers for constructive comments on the previous version of the manuscript.

\section{References}

Alam MS, Jia Z (2012) Inhibition of methane oxidation by nitrogenous fertilizers in a paddy soil. Front Microbiol 3:246

Angel R, Matthies D, Conrad R (2011) Activation of methanogenesis in arid biological soil crusts despite the presence of oxygen. PLoS One. doi:10.1371/journal.pone.0020453

Angel R, Claus P, Conrad R (2012) Methanogenic archaea are globally ubiquitous in aerated soils and become active under wet anoxic conditions. ISME J 6:847-862

Bao Q, Huang Y, Wang F, Nie S, Nicol GW, Yao H, Ding L (2016) Effect of nitrogen fertilizer and/or rice straw amendment on methanogenic archaeal communities and methane production from a rice paddy soil. Appl Microbiol Biot 13:5989-5998

Bodelier PL, Roslev P, Henckel T, Frenzel P (2000) Stimulation by ammonium-based fertilizers of methane oxidation in soil around rice roots. Nature 403:421-424

Brioukhanov A, Netrusov A, Sordel M, Thauer RK, Shima S (2000) Protection of Methanosarcina barkeri against oxidative stress: identification and characterization of an iron superoxide dismutase. Arch Microbiol 174:213-216

Dan JG, Krüger M, Frenzel P, Conrad R (2001) Effect of a late season urea fertilization on methane emission from a rice field in Italy. Agric Ecosyst Environ 83:191-199

Erkel C, Kube M, Reinhardt R, Liesack W (2006) Genome of rice cluster I archaea - the key methane producers in the rice rhizosphere. Science 313:370-372

Eusufzai MK, Tokida T, Okada M, Si S, Liu GC, Nakajima M, Sameshima R (2010) Methane emission from rice fields as affected by land use change. Agric Ecosyst Environ 139:742-748

Fan X, Yu H, Wu Q, Ma J, Xu H, Yang J, Zhuang Y (2016) Effects of fertilization on microbial abundance and emissions of greenhouse gases $\left(\mathrm{CH}_{4}\right.$ and $\left.\mathrm{N}_{2} \mathrm{O}\right)$ in rice paddy fields. Ecol Evol 6:1054-1063

Freitag TE, Prosser JI (2009) Correlation of methane production and functional gene transcriptional activity in a peat soil. Appl Environ Microbiol 75:6679-6687

Hales BA, Edwards C, Ritchie DA, Hall G, Pickup RW, Saunders JR (1996) Isolation and identification of methanogen-specific DNA from blanket bog feat by PCR amplification and sequence analysis. Appl Environ Microbiol 62:668-675

Hanson R, Hanson T (1996) Methanotrophic bacteria. Microbiol Mol Biol R 60:439-471

Henckel T, Friedrich M, Conrad R (1999) Molecular analyses of the methane-oxidizing microbial community in rice field soil by targeting the genes of the $16 \mathrm{~S}$ rRNA, particulate methane monooxygenase, and methanol dehydrogenase. Appl Environ Microbiol 65:1980-1990

Ho A, Lüke C, Reim A (2016) Resilience of (seed bank) aerobic methanotrophs and methanotrophic activity to desiccation and heat stress. Soil Biol Biochem 101:130-138

Hu HW, Zhang LM, Yuan CL, He JZ (2013) Contrasting Euryarchaeota communities between upland and paddy soils exhibited similar $\mathrm{pH}-$ impacted biogeographic patterns. Soil Biol Biochem 64:18-27

Intergovernmental Panel on Climate Change (IPCC) (2013) In: Denman KL (ed) Couplings between changes in the climate system and biochemistry. Climate change 2013: the physical science basis. Cambridge University Press, Cambridge

Inubushi K, Furukawa Y, Hadi A, Purnomo E, Tsuruta H (2003) Seasonal changes of $\mathrm{CO}_{2}, \mathrm{CH}_{4}$ and $\mathrm{N}_{2} \mathrm{O}$ fluxes in relation to land-use change in tropical peatlands located in coastal area of South Kalimantan. Chemosphere 52:603-608

Jaatinen K, Knief C, Dunfield PF, Yrjala K, Fritze H (2004) Methanotrophic bacteria in boreal forest soil after fire. FEMS Microbiol Ecol 50:195-202

Jäckel U, Schnell S, Conrad R (2001) Effect of moisture, texture and aggregate size of paddy soil on production and consumption of $\mathrm{CH}_{4}$. Soil Biol Biochem 33:965-971

Jetten MSM, Stams AJM, Zehnder AJB (1990) Purification and some properties of the methyl-com reductase of MethanothrixSoehngenii. FEMS Microbiol Lett 66:183-186

Knief C, Kolb S, Bodelier PL, Lipski A, Dunfield PF (2006) The active methanotrophic community in hydromorphic soils changes in response to changing methane concentration. Environmen Microbol 8:321-333

Krüger M, Frenzel P, Kemnitz D, Conrad R (2005) Activity, structure and dynamics of the methanogenic archaeal community in a flooded Italian rice field. FEMS Microbiol Ecol 51:323-331

Lammel DR, Feigl BJ, Cerri CC, Nüsslein K (2015) Specific microbial gene abundances and soil parameters contribute to $\mathrm{C}, \mathrm{N}$, and greenhouse gas process rates after land use change in southern Amazonian soils. Front Microbiol 6. doi:10.3389/fmicb.2015.01057

Lee HJ, Kim SY, Kim PJ, Madsen EL, Jeon CO (2014) Methane emission and dynamics of methanotrophic and methanogenic communities in a flooded rice field ecosystem. FEMS Microbiol Ecol 88:195-212

Liu D, Ishikawa H, Nishida M, Tsuchiya K, Takahashi T, Kimura M, Asakawa S (2015a) Effect of paddy-upland rotation on methanogenic archaeal community structure in paddy field soil. Microb Ecol 69: $160-168$

Liu S, Hu Z, Wu S, Li S, Li Z, Zou J (2015b) Methane and nitrous oxide emissions reduced following conversion of Rice paddies to inland crab-fish aquaculture in Southeast China. Environ Sci Technol 50: 633-642

Liu H, Liu G, Li Y, Wu X, Liu D, Xu M, Dai X, Yang F (2016) Effects of land use conversion and fertilization on $\mathrm{CH}_{4}$ and $\mathrm{N}_{2} \mathrm{O}$ fluxes from typical hilly red soil. Environ Sci Pollut Res 23:20269-20280

Lu Y, Conrad R (2005) In situ stable isotope probing of methanogenic archaea in the rice rhizosphere. Science 309:1088-1090

Ma K, Lu Y (2011) Regulation of microbial methane production and oxidation by intermittent drainage in rice field soil. FEMS Microbiol Ecol 75:446-456

McDonald IR, Bodrossy L, Chen Y, Murrell JC (2008) Molecular ecology techniques for the study of aerobic methanotrophs. Appl Environ Microbiol 74:1305-1315

Metje M, Frenzel P (2007) Methanogenesis and methanogenic pathways in a peat from subarctic permafrost. Environ Microbiol 9:954-964

Mohanty SR, Bodelier PL, Floris V, Conrad R (2006) Differential effects of nitrogenous fertilizers on methane-consuming microbes in rice field and forest soils. Appl Environ Microbiol 72:1346-1354

Mohanty SR, Tiwari S, Dubey G, Ahirwar U, Kollah B (2016) How methane feedback response influence redox processes in a tropical vertisol. Biol Fert Soils 53:479-490

Nishimura S, Yonemura S, Sawamoto T, Shirato Y, Akiyama H, Sudo S, Yagi K (2008) Effect of land use change from paddy rice cultivation to upland crop cultivation on soil carbon budget of a cropland in Japan. Agricul Ecosys Environ 125:9-20

Noll M, Frenzel P, Conrad R (2008) Selective stimulation of type I methanotrophs in a rice paddy soil by urea fertilization revealed by RNA-based stable isotope probing. FEMS Microbiol Ecol 65:125132

Reay DS, Nedwell DB (2004) Methane oxidation in temperate soils: effects of inorganic N. Soil Biol Biochem 36:2059-2065

Sass RL, Fisher FM, Lewis ST, Jund MF, Turner FT (1994) Methane emissions from rice fields-effect of soil properties. Global Biogeochem CY 8:135-140 
Scavino AF, Ji Y, Pump J, Klose M, Claus P, Conrad R (2013) Structure and function of the methanogenic microbial communities in Uruguayan soils shifted between pasture and irrigated rice fields. Environ Microbiol 15:2588-2602

Scheer C, Wassmann R, Kienzler K, Ibragimov N, Lamers J, Martius C (2008) Methane and nitrous oxide fluxes in annual and perennial land-use systems of the irrigated areas in the Aral Sea basin. Glob Chang Biol 14:2454-2468

Schimel J (2000) Global change: rice, microbes and methane. Nature 403: 375-377

Singh BK, Tate KR (2007) Biochemical and molecular characterization of methanotrophs in soil from a pristine New Zealand beech forest. FEMS Microbiol Lett 275:89-97

Singh BK, Tate KR, Ross DJ, Singh J, Dando J, Thomas N, Murrell JC (2009) Soil methane oxidation and methanotroph responses to afforestation of pastures with Pinus radiata stands. Soil Biol Biochem 41:2196-2205

Szubert J, Reiff C, Thorburn A, Singh BK (2007) REMA: a computerbased mapping tool for analysis of restriction sites in multiple DNA sequences. J Microbiol Meth 69:411-413

Tamura K, Stecher G, Peterson D, Filipski A, Kumar S (2013) MEGA6: molecular evolutionary genetics analysis version 6.0. Mol Bio Evol $30: 2725-2729$
Wang L, Pan Z, Xu H, Wang C, Gao L (2015) The influence of nitrogen fertiliser rate and crop rotation on soil methane flux in rain-fed potato fields in Wuchuan County, China. Sci Total Environ 537: 93-99

Watanabe T, Kimura M, Asakawa S (2007) Dynamics of methanogenic archaeal communities based on rRNA analysis and their relation to methanogenic activity in Japanese paddy field soils. Soil Biol Biochem 39:2877-2887

Yan XY, Akiyama H, Yagi K, Akimoto H (2009) Global estimations of the inventory and mitigation potential of methane emissions from rice cultivation conducted using the 2006 intergovernmental panel on climate change guidelines. Global Biogeochem CY. doi:10.1029 /2008GB003299

Zheng Y, Liu X, Zhang L, Zhou Z, He J (2010) Do land utilization patterns affect methanotrophic communities in a Chinese upland red soil? J Environ Sci-China 22:1936-1943

Zhou B, Wang Y, Feng Y, Lin X (2016) The application of rapidly composted manure decreases paddy $\mathrm{CH}_{4}$ emission by adversely influencing methanogenic archaeal community: a greenhouse study. J Soils Sediments 16:1889-1990

Zou JW, Huang Y, Jiang JY, Zheng XH, Sass RL (2005) A 3-year field measurement of methane and nitrous oxide emissions from rice paddies in China: effects of water regime, crop residue, and fertilizer application. Global Biogeochem CY. doi:10.1029/2004gb002401 